\title{
What psychiatrists think about Part III of the Mental Health Act 1983
}

\author{
Alec Buchanan and John Gunn
}

\begin{abstract}
Alms and method The government has proposed a 'root and branch' review of the Mental Health Act 1983 to be conducted by the end of 1999. The aim of the study was to establish the views of general and forensic psychiatrists as to the adequacy of present legislattve provision for England and Wales. The study was carried out by postal survey.

Results The response rates were $82 \%$, for forensic psychiatrists and 67\%, for general psychiatrists. Most respondents considered most of present provision satisfactory. Areas considered in need of amendment were: the term 'psychopathic disorder'; the requirement for an offence punishable by imprisonment before a hospital order can be made. provision for remands to hosplital and the loss of clinical independence consequent upon the making of a restriction order.

Clinical implications Forensic psychiatrists seem more willing than general psychiatrists to see their clinical discretion limited by the courts. Most of the suggestions were for changes to individual aspects of the present legislation rather than radical reform.
\end{abstract}

Part III of the Mental Health Act 1983 caters for mentally disordered people in the criminal justice system of England and Wales. Equivalent (but not identical) provision for the rest of the UK is contained in the Criminal Procedure (Scotland) Act 1975 and the Mental Health (Northern Ireland) Order 1986. Part III provides for remand to hospital for reports (under Section 35) or treatment (Section 36); hospital, guardianship and place of safety orders (Section 37); restriction orders and restriction directions (Sections 41 and 49) and the removal to hospital of sentenced and un-sentenced prisoners (Sections 47 and 48). The number of orders made under Part III of the Act increased from 1389 in 1984 to 2018 in 1996 . The present research was designed to find out what forensic and general psychiatrists think of Part III and how they think it could be improved.

\section{The study}

A list of the members of two faculties of the Royal College of Psychiatrists, Forensic Psychiatry and General and Community Psychiatry, was obtained. All of the forensic psychiatrists in England and Wales ( $n=133)$ and a random sample of 91 general and community psychiatrists were sent a questionnaire. Those who failed to respond were prompted once. Response rates after prompting were $\mathbf{8 2} \%$ for forensic psychiatrists and $67 \%$ for their general and community colleagues. The questionnaire contained 14 items listed in Tables 1 and 2. Each item required the psychiatrists to describe an aspect of the wording of the Act as 'satisfactory' or 'in need of amendment'. The responses are shown in the Appendix. The proportion of subjects deeming unsatisfactory each aspect of the wording is shown in Tables 1 and 2. The tables indicate also those items in respect of which the views of the two groups differed. Subjects were invited also to expand on their views in relation to each item. Excerpts of subjects' views and details of tests of significance are given in the text.

\section{Findings}

\section{Criteria for detention}

Most of those who responded were content that mental illness is not defined by the Mental Health Act (Item 1.1). One general psychiatrist reflected that the "dynamic tension" between mental illness as defined by law and as defined by psychiatrists was all to the good. General and community psychiatrists were more likely to want change $\left(\chi^{2}=10.8\right.$, d.f. $\left.=1, P<0.001\right)$. The most common suggestion of those who described the changes they would like to see was for an expanded definition using such terms as 'psychotic illness', 'organic illness' and 'severe neurotic depression'.

Most respondents were unhappy about the inclusion in the Act of 'psychopathic disorder' as currently defined (Item 1.2). Thirty-two per cent 
Table 1. Proportion of psychiatrists deeming "in need of amendment" criteria used in the Mental Health Act 1983

\begin{tabular}{|c|c|c|c|}
\hline Ifem & $\begin{array}{l}\text { Forenalc } \\
\text { poychlatists (\%) }\end{array}$ & $\begin{array}{l}\text { General } \\
\text { poychiatilists (\%) }\end{array}$ & Signilicance \\
\hline $\begin{array}{l}\text { 1.1 The term mental illness is not defined } \\
\text { 1.2 The law uses the term 'psychopathic disorder' } \\
\text { 1.3 In cases of psychopathic disorder and mental } \\
\text { impairment the law distinguishes treatment } \\
\text { "llikely to alleviate or prevent a deterioration" } \\
\text { from other treatment }\end{array}$ & $\begin{array}{l}22 \\
68 \\
37\end{array}$ & $\begin{array}{l}46 \\
64 \\
46\end{array}$ & $\begin{array}{l}\text { NS } \\
\text { NS }\end{array}$ \\
\hline $\begin{array}{l}\text { 1.4 Remands for treatment, hospltal orders and transfers } \\
\text { of prisoners to hospltal require a disorder of } \\
\text { a "nature or degree which makes it appropriate } \\
\text { for him to be detained in a hospltal for medical } \\
\text { treatment" }\end{array}$ & 19 & 16 & NS \\
\hline $\begin{array}{l}\text { 1.5 An interim hospltal order can only be made where } \\
\text { it is reasonable to suppose that a hospltal order } \\
\text { may be appropriate }\end{array}$ & 8 & 14 & NS \\
\hline $\begin{array}{l}\text { 1.6 A hospltal order can only be made if the offence } \\
\text { can attract a custodial sentence }\end{array}$ & 38 & 70 & * \\
\hline $\begin{array}{l}\text { 1.7 A restriction order reflects, "the nature of the } \\
\text { offence, the antecedents of the offender and } \\
\text { the risk of him commilting further offences if set } \\
\text { at large" }\end{array}$ & 18 & 23 & NS \\
\hline
\end{tabular}

NS, not significant.

$\bullet P<0.01$.

Table 2. Proportion of psychiatrists deeming "in need of amendment" the powers and provisions created by the Mental Health Act 1983

\begin{tabular}{|c|c|c|c|}
\hline lifem & $\begin{array}{l}\text { Forensic } \\
\text { Poychiatitats (\%) }\end{array}$ & $\begin{array}{l}\text { Generd } \\
\text { poychlatilists (\%) }\end{array}$ & Signiliconce \\
\hline $\begin{array}{l}\text { 2.1 Remands for reports are distinguished from remands } \\
\text { for treatment }\end{array}$ & 56 & 43 & NS \\
\hline $\begin{array}{l}2.2 \text { The law falls to make explicit whether a treatment } \\
\text { order (Section 3) can be applled to a patient } \\
\text { remanded to hospltal for reports }\end{array}$ & 87 & 92 & NS \\
\hline $\begin{array}{l}2.3 \text { Time limits. Before an order can be made, a bed } \\
\text { must be available within } 7 \text { days (remand orders) } \\
\text { or } 28 \text { days (hosplital orders and interim hospltal } \\
\text { orders) }\end{array}$ & 42 & 38 & NS \\
\hline $\begin{array}{l}2.4 \text { Renewals. Remands for reports or treatment need } \\
\text { to be renewed after } 28 \text { days and this can only } \\
\text { be done up to a maximum of } 12 \text { weeks }\end{array}$ & 51 & 39 & NS \\
\hline $\begin{array}{l}2.5 \text { A restriction order removes the doctor's power } \\
\text { independently to discharge }\end{array}$ & 19 & 55 & * \\
\hline $\begin{array}{l}\text { 2.6 After the conditional discharge of a restriction order, } \\
\text { medical supervisors are expected to report to the } \\
\text { Home Office every three months }\end{array}$ & 31 & 46 & NS \\
\hline $\begin{array}{l}\text { 2.7 Transfer directions allow the removal to hospital of } \\
\text { prisoners }\end{array}$ & 15 & 32 & * \\
\hline
\end{tabular}

NS, not significant.

$* P<0.01$

of those who expanded on their views (who, in turn, comprised $22 \%$ of respondents) thought that the term should simply be removed without making alternative provision. Fifty-one per cent, however, wanted the retention of a category specifically to cover the personality disorders.
Suggestions included replacing 'psychopathic disorder' with an operational definition of personality disorder and limiting the applicability of the Act to 'severe' or 'persistent' cases. Some forensic psychiatrists, but no general psychiatrists, suggested that the definition 
should specifically include addictions and paraphilias.

Nearly half of respondents thought that the reference to treatment likely to alleviate or prevent a deterioration in the patient's condition' was in need of amendment (Item 1.3). The most common complaint was that the phrase is too vague, a view borne out by claims, from a forensic and a general psychiatrist respectively, that the so called 'treatability clause' firstly, covers everyone and secondly, covers no-one. Suggestions for change ranged from omitting the clause altogether to defining it in such a way that the required likely response to treatment was spelled out.

The criteria relating to transfer from prison to hospital, the making of interim hospital orders and the making of restriction orders caused relatively little concern to psychiatrists (Items $1.4,1.5$ and 1.7). The requirement for the commission of an offence punishable by imprisonment before a hospital order can be made, however, was regarded as unsatisfactory by over two-thirds of general and community psychiatrist respondents (Item 1.6). They wanted to see the requirement replaced by criteria, similar to those contained in Sections 2 and 3 of the Mental Health Act, related to medical needs. One respondent reflected that the hospital order could then become a civil order under a procedure similar to that of 'certification' which preceded the Mental Health Act 1957. General psychiatrists were more likely than forensic psychiatrists to consider this aspect of the law in need of amendment $\left(\chi^{2}=10.8\right.$; d.f. $\left.=1 ; P<0.001\right)$.

\section{Powers and provisions}

Half the respondents wanted to see the replacement of Section 35 (remands for reports) and Section 36 (remands for treatment) with a new order, in the words of one, "for assessment, and treatment where necessary" (see Table 2). If the two sections are to remain, our respondents argued, they should be made more flexble. Suggestions included allowing the conversion of Section 35 to Section 36 without a return to court, making Section 36 available at magistrates' courts, permitting the making of remand orders where the charge is one of murder, requiring only a "suspicion of mental disorder" before an order can be made and allowing magistrates' courts to make orders under Section 35 in respect of indictable offences. These suggestions would also address the near unanimous desire for clarity over the legality of treatment orders made in respect of people remanded to hospital for reports (see Table 2).

About $40 \%$ were unhappy with the time limits on bed availability which apply to remand and hospital orders (see Table 2). Most wanted these extended, some arguing that open ended orders would increase the political pressure to provide sufficient beds as the number of prisoners subject to remand orders but remaining in prison built up. Others feared that extending the time limits for remand orders would exacerbate the effect whereby recommendation for psychiatric disposal increases the length of time spent in prison on remand (Robertson et al, 1994). A similar desire for flexibility seemed to lie behind dissatisfaction with the need to renew these orders (Table 2). Most of those advocating amendment wanted initial periods increased to six, or even 12 months while others thought that remand orders should simply continue until the case is dealt with by the courts.

General psychiatrists were significantly more likely to object to the need for the Home Secretary's approval before a patient on a restriction order can go on leave or be discharged from hospital $\left(\chi^{2}=22.7\right.$; d.f. $\left.=1 ; P<0.001\right)$ and more than half did so. Some safeguards may be acceptable, one wrote, but the present degree of political influence was not. Another thought that all such orders should be time limited, with extensions possible only after a review of the case by a mental health review tribunal. Forensic psychiatrists, perhaps as a consequence of being more familiar with it, were more likely to comment on details of the legislation. They wanted more discretion for psychiatrists to grant leave and even conditionally to discharge restricted patients. The substantial minority who found the reporting requirements in need of amendment was also concerned with the lack of flexdbility in current provision.

One-third of general psychiatrists found it unsatisfactory that legislation exists to allow the transfer to hospital of prisoners to hospital under Section 47 (which provides for the treatment of sentenced prisoners) and Section 48 (urgent cases on remand: see Table 2). None gave their reasons. Forensic psychiatrists were less likely to regard present provision as unsatisfactory $\left(\chi^{2}=6.9 ;\right.$ d.f. $\left.=1 ; P<0.001\right)$ and those who did so restricted themselves to suggesting minor amendments. One wanted the inclusion of the term "for assessment" in any replacement of Section 47. Another suggested that the term 'urgent' be removed from Section 48 and that the same section be extended to cover all forms of mental disorder, not just mental lliness and severe mental impairment. One complained that present provision allowed doctors to have foisted on them people whom they have assessed as untreatable and concern was expressed also that prison transfers were abused to provide public protection in cases where dangerous prisoners were approaching the end of their sentences. 


\section{Other concerns of respondents}

Of the areas not currently covered by the Mental Health Act, that mentioned most frequently was the lack of a mechanism to ensure compulsory treatment in the community. Some subjects suggested a community treatment order designed to resemble a conditionally discharged restriction order. One suggested a "guardianship board" to supervise and initiate the making of such orders. Others emphasised that resources, not laws, were the determinants of the quality of care received and any legislation should be explicit in its requirement for an adequate range of mental health service provision. Not all were critical. "The more I think about the Mental Health Act", wrote one forensic psychiatrist, "the more impressed I am by its drafting".

\section{Discussion}

The response rate, particularly among forensic psychiatrists who have the greatest exposure to Part III of the Mental Health Act 1983, was sufficiently good that the views of respondents are likely to be representative. There will be some 'grumble bias' because those dissatisfied with the status quo will have been more likely to return their questionnaire. This will particularly have been the case where psychiatrists were asked to expand on their views, since only a minority of respondents did so. We have not attempted to address the use of the Act in relation to patients with learning disabilities, a subject which has generated its own literature (Kon \& Bouras, 1996). With these reservations, forensic and general psychiatrists were dissatisfied with large sections of the Mental Health Act.

Two-thirds of both groups considered current use of the term psychopathic disorder to be in need of amendment. This is more than the $47 \%$ of forensic psychiatrists who told Cope (1993) that the term should be dropped. Forensic psychiatry has expanded in the years since Cope's paper and the new intake, younger and more recently trained, may be more antipathetic. The suggestion that personality disorder replace psychopathic disorder was made also in the Reed Report (Department of Health and Social Security \& Home Office, 1992). Dissatisfaction with the requirement that treatment of psychopathic disorder be likely to alleviate or prevent a deterioration echoes concerns that the treatment of other conditions is not contingent on successful outcome and that, in cases of personality disorder, improvement, unless measured purely in terms of behaviour, is difficult to assess (Chiswick, 1992). One suggested solution is that people with a primary diagnosis of personality disorder who have been convicted of an imprisonable offence should only come into hospital as prison transfers (Mawson, 1983; Grounds, 1987). This seems likely to be opposed by the one-third of general psychiatrists who think that such transfers should not take place at all.

Disaffection with the present distinction between remands for reports and remands for treatment reflects the views of those who have advocated increasing the flexibility of present provision (Exworthy \& Glen, 1992) or amending Sections 2 and 3 of the Act to include prisoners on remand (Mental Health Act Commission, 1993: Akinkunmi \& Murray, 1997). Replacing Sections 35 and 36 with one new section to cover all remand cases was first suggested by the Mental Health Act Commission (1987). The responses relating to time limits, renewals and reporting requirements for conditionally discharged patients are calls for greater discretion and flexibility. Since none of the general psychiatrists who objected to the transfer to hospital of prisoners gave their reason for doing so it is possible only to speculate. The most likely alternative is that they preferred to see psychiatric treatment provided within the prison system. Despite their concerns, official figures show that what some regarded as the neglect of Section 48 (Exworthy et al, 1992) has been followed, in the present decade, by increased use of these orders.

Forensic psychiatrists were less concerned than general psychiatrists that hospital orders are only an option where the offence can attract a custodial sentence and less concerned about the loss of medical independence implicit in the making of a restriction order. That they were more willing than general psychiatrists to leave the term 'mental illness' undefined suggests that, while forensic psychiatrists value their discretion in deciding what is and is not mental illness, they were more willing than their general colleagues to have the application of that discretion limited by the court. The responses in relation to hospital orders, and in particular, the fact that only one respondent suggested that a hospital order should only be made where the offence was a result of illness, reflect overwhelming support for the principle of disengaging medical need from absence of moral responsibility and for continuing to make compulsory admission dependent on the former, not the latter.

Since we undertook this survey the government has announced a 'root and branch' review of mental health legislation. The evidence here suggests that, while the psychiatric profession has some suggestions for improvement, there is little demand for sweeping change. This will especially be the case where changes are not thoroughly canvassed and discussed beforehand. We believe that it would be helpful were the government to obtain the views of those professionals who will have to operate any new 
mental health legislation. Psychiatrists, nurses, social workers, policemen and others need to be surveyed. Surveys such as this are not expensive. The expenditure of a small amount of money and a few months of extra data gathering and thinking time could make the government's proposed new mental health legislation more soundly based and more likely to be operated effectively by the professions involved.

\section{References}

AKINKUNMI, A. \& MURRAY, K. (1997) Inadequacies in the Mental Health Act, 1983 in relation to mentally disordered remand prisoners. Medicine. Science and the Law. 37, 53-57.

CHISwCK. D. (1992) Compulsory treatment of patients with psychopathic disorder: an abnormally aggressive or sertously irresponsible exercise: Criminal Behaviour and Mental Health, 2, 106-113.

COPE, R. (1993) A survey of forensic psychiatrists' views on psychopathic disorder. Journal of Forensic Psychiatry. 4. 215-235.

Department of HEalth and SOCIAL SECuRTty \& Home OfFice (1992) Review of Health and Social Services for Mentally Disordered Offenders and Others Requiring Similar Services. The Reed Report. London: HMSO.

ExwORTHY, T., PARROTT, J. \& BRIDGES, P. (1992) Section 48: an underused provision? Psychiatric Bulletin. 16. 97-98.

- \& GLEN, C. (1992) A case for change: Section 35, Menta Health Act 1983. Justice of the Peace. 166, 663-664.

GROUNDS, A. T. (1987) Detention of 'psychopathic disorder' patients in special hospital: critical issues. British Journal of Psychiatry, 151, 474-478.

KON, Y. \& BOURAS, N. (1996) The use of the Mental Health Act in learning disabilities. Psychiatric Bulletin. 20 596-598.

MawsoN, D. (1983) 'Psychopaths' in Special Hospitals Bulletin of the Royal College of Psychiatrists, 7, 178-181.

MENTAL HEALTH ACT Commission (1987) Second Biennial Report. 1985-1987. London: HMSO.

- (1993) Fyth Biennial Report. 1991-1993. London: HMSO.

Robertson, G., Deu, S., James, K., et al (1994) Psychotic men remanded in custody to Brixton prison. British Joumal of Psychiatry. 164, 55-61.

*Alec Buchanan, Clinical Senior Lecturer in Forensic Psychiatry, and John Gunn, Professor of Forensic Psychiatry, Institute of Psychiatry, Denmark Hill, London SE5 8AF

*Correspondence

\section{Appendix}

Numbers of psychiatrists deeming "satisfactory" and "in need of amendment" the criteria used and the powers and provisions created by the Mental Health Act 1983

\begin{tabular}{|c|c|c|}
\hline Ifem & $\begin{array}{l}\text { Forensic } \\
\text { poychiatilsts } \\
(n)\end{array}$ & $\begin{array}{l}\text { General } \\
\text { psychiaitists } \\
\text { (n) }\end{array}$ \\
\hline \multicolumn{3}{|l|}{1.1} \\
\hline $\begin{array}{l}\text { Satisfactory } \\
\text { In need of amendment } \\
1.2\end{array}$ & $\begin{array}{l}85 \\
24\end{array}$ & $\begin{array}{l}34 \\
29\end{array}$ \\
\hline $\begin{array}{l}\text { Satisfactory } \\
\text { In need of amendment } \\
1.3\end{array}$ & $\begin{array}{l}35 \\
74\end{array}$ & $\begin{array}{l}23 \\
41\end{array}$ \\
\hline $\begin{array}{l}1.3 \\
\text { Satisfactory } \\
\text { In need of amendment }\end{array}$ & $\begin{array}{l}67 \\
40\end{array}$ & $\begin{array}{l}34 \\
29\end{array}$ \\
\hline $\begin{array}{l}1.4 \\
\text { Satisfactory }\end{array}$ & 88 & 52 \\
\hline $\begin{array}{l}\text { In neөd of amendment } \\
1.5\end{array}$ & 21 & 10 \\
\hline $\begin{array}{l}\text { Satisfactory } \\
\text { In need of amendment }\end{array}$ & $\begin{array}{r}99 \\
8\end{array}$ & $\begin{array}{r}50 \\
8\end{array}$ \\
\hline $\begin{array}{l}\text { Satisfactory } \\
\text { In need of amendment }\end{array}$ & $\begin{array}{l}66 \\
40\end{array}$ & $\begin{array}{l}18 \\
42\end{array}$ \\
\hline 1.7 & & \\
\hline $\begin{array}{l}\text { Satisfactory } \\
\text { In need of amendment } \\
2.1\end{array}$ & $\begin{array}{l}88 \\
19\end{array}$ & $\begin{array}{l}47 \\
14\end{array}$ \\
\hline $\begin{array}{l}\text { Satisfactory } \\
\text { In need of amendment } \\
2.2\end{array}$ & $\begin{array}{l}48 \\
61\end{array}$ & $\begin{array}{l}34 \\
26\end{array}$ \\
\hline $\begin{array}{l}\text { Satisfactory } \\
\text { In need of amendment } \\
2.3\end{array}$ & $\begin{array}{l}14 \\
94\end{array}$ & $\begin{array}{r}5 \\
56\end{array}$ \\
\hline Satisfactory & 63 & 37 \\
\hline $\begin{array}{l}\text { In need of amendment } \\
2.4\end{array}$ & 45 & 23 \\
\hline $\begin{array}{l}\text { Satisfactory } \\
\text { In need of amendment } \\
2.5\end{array}$ & $\begin{array}{l}53 \\
55\end{array}$ & $\begin{array}{l}35 \\
22\end{array}$ \\
\hline $\begin{array}{l}\text { Satisfactory } \\
\text { In neөd of amendment } \\
2.6\end{array}$ & $\begin{array}{l}88 \\
21\end{array}$ & $\begin{array}{l}27 \\
33\end{array}$ \\
\hline $\begin{array}{l}\text { Satisfactory } \\
\text { In need of amendment } \\
2.7\end{array}$ & $\begin{array}{l}73 \\
33\end{array}$ & $\begin{array}{l}33 \\
28\end{array}$ \\
\hline $\begin{array}{l}\text { Satisfactory } \\
\text { in neөd of amendment }\end{array}$ & $\begin{array}{l}93 \\
16\end{array}$ & $\begin{array}{l}38 \\
18\end{array}$ \\
\hline
\end{tabular}

